\title{
Before Religion: A History of a Modern Concept, by Brent Nongbri
}

New Haven and London: Yale University Press, 2013 | ix +275 pages | ISBN: 978-0-300-I 54I6-0 (hardcover) \$40.00

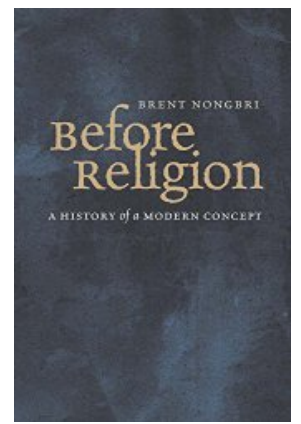

Brent Nongbri has written a notable introductory text on the history of the concept of "religion," drawing heavily from the works of other influential scholars in the field, such as Wilfred Cantwell Smith, Talal Asad, Tomoko Masuzawa, David Chidester, and Russell McCutcheon to name a few. The basic thesis of his book is that "religion is a modern and not an ancient concept" (I2), with "modern" referring to the middle of the fifteenth century onwards. For Nongbri, it is during that period that "distinctions between 'the religious' and 'the secular" ( 5 ) arose, thus demarcating the beginnings of the modern usage of the term. As such, religion "is not a native category to ancient cultures" (7) as Nongbri argues, following the famous statement by Jonathan Z. Smith. It is exactly that history of the term that constitutes the central topic of this volume.

However, tracing the history of the term does not simultaneously mean that a satisfactory definition of "religion" will somehow emerge or reveal itself through such a historical study. Nongbri makes sure in his first chapter, "What do We Mean by 'Religion," to point out right from the outset that attempts by modern scholars to define religion have proved to be, to say the least, futile. Based on the very fact that most scholars have approached the tantalizing issue of defining religion starting from a common denominator, i.e., that religion in its modern expression as a category is related to the Protestant usage of the term, Nongbri offers a (subtractive) definition based on its use in the modern western world: "religion is anything that sufficiently resembles modern Protestant Christianity" (I 8).

Even though postcolonial scholars have continually stressed what Nongbri here rightly points out, the issue of whether the term "religion" can or should be used as common descriptor for modern phenomena is more complicated than simply pointing it out. After all, isn't the term "religion" now also "property" of modern people outside the so-called Western world? As such, an enterprise of tracing the history of the term "religion" must, at the same time, deal with how and when the category was eventually adopted and used by the cultures upon which it was initially imposed - an issue that 
Nongbri does not address. If such an enterprise seems possible in a contemporary cross-cultural historical research, it becomes nevertheless impossible when we turn our attention to the ancient world.

Chapter 2, "Lost in Translation: Inserting 'Religion' into Ancient Texts," deals with a profoundly important issue in the study of the category "religion." Among various options, Nongbri concentrates on three terms, i.e., the Latin religio, the Greek threskeia, and the Arabic dìn. The main point here is the illustration of the problems that arise when scholars encounter the aforementioned terms "in modern translations as 'religion" while "the contexts in which these terms occur often make such translations problematic" (26). Nongbri examines various instances where those terms appear and shows that "the entities being classified should not be confused with the modern religions" since such a misguided translation is "bound to be a misleading practice" (45). I should add at this point that the discussion around the term threskeía (34-38) is not as detailed as the other two of Nongbri's examples, while the term hairesis (36) is not adequately discussed since it has a history of meaning, as does the term "religion," changing from "choice" to "heresy."

In the next two chapters Nongbri turns his attention to the examination of certain historical moments that for scholars signal the emergence of religion in the modern sense ("Some (Premature) Births of Religion in Antiquity") and, then, the way ancient groups attempted to distinguish themselves from others by employing different strategies that have little to do with the modern discourse on ancient religions ("Christians and 'Others' in the Premodern Era”). Presenting examples that range from the Revolt of the Maccabees and the function of the term religio in the works of Cicero to Manichaeism — as an allegedly straightforward case of the emergence of religion before the modern period-and early Islam as a Christian heresy in the works of early Christian writers, Nongbri shows not only that the term "religion" causes "more problems than it solves" (64) but, more importantly, by employing such a terminology modern scholars create "boundaries that are alien to the boundaries the ancient authors constructed" (84). These two chapters are extremely well structured and clearly show Nongbri's knowledge of the premodern era and the ease with which he moves between primary sources and theoretical issues.

Chapters 5 ("Renaissance, Reformation, and Religion in the Sixteenth and Seventeenth Centuries") and 6 ("New Worlds, New Religions, World Religions") constitute a succinct discussion of how and when the distinction 
between "religious" and "secular" emerged and became the dominant "way of conceiving of the world" (85). This development within the European locale led to the "production of the modern concept of religion" (I06), which resulted - through trade and colonization - to the formation of what, already from the nineteenth century, is known as "the modern framework of World Religions" (124). With these two chapters, Nongbri concludes the historical survey of his project in order to return to the ancient world but, now, from a different perspective: to deal with the so-called "ancient religions" based on the developments already discussed that led to the emergence of the categories "religion" and "World Religions."

The seventh and last chapter, "The Modern Origins of Ancient Religions," concentrates on "how and why we have come to speak so easily of ancient religions" (132) when, obviously, the category is a recent development. Nongbri traces the origins of such a classification of ancient practices in the same colonial era during which the term "religion" emerged as well as during the rise of Romanticism in Europe. The latter caused a "renewed European interest in mythology fueled (and was itself fueled by) nationalist concerns" (I 40). As with all similar phenomena across time and space, the matter of "origins" is always both at stake and at the core of such ideologies, and a renewed interest of what was seen as ancient "religions" was at work during this period of European history. As Nongbri rightly emphasizes, the twentieth-century turn towards the actual facts and figures of ancient "religions," as prominent classicists have shown, shares very little with how the modern concept is conceived and understood. Nevertheless, scholars of antiquity still call these phenomena "religions," which justifiably urges Nongbri to ask: "if the things that modern people conceive of as 'religious' were not so conceived in the ancient worlds and vice versa, then how and why are ancient practices to be recognized as 'religion' at all?" (I 43). This chapter concludes with Nongbri arguing that any conversations about "ancient religions" inevitably bring into the picture two contradictory terms. Insisting to use the modern concept of religion upon ancient practices and configurations without acknowledging the anachronism at work, or making clear how the term is used, only means that eventually "we turn our ancient sources into well-polished mirrors that show us only ourselves and our own institutions" (I 53 ).

One would expect Nongbri to offer either an alternative term or disregard altogether the category "religion" as a scholarly tool in studying antiquity. Surprisingly, however, he chooses another path in his epilogue ("Con- 
clusion: After Religion?"). After a short summary of what this book is all about-concentrating on the history of the term "religion," the distinction between ancient and modern worlds and between "descriptive and redescriptive usages of religion" (I 54)-Nongbri does not share (as one would expect) the suggestions to abandon the term offered by other scholars such as Wilfred Cantwell Smith and Timothy Fitzgerald. On the contrary, "religion" may continue to be a scholarly term as long as "we are going to use religion as a second-order, redescriptive concept" being "explicit that we are doing so and avoid giving the impression that religion really was 'out there,' 'embedded in' or 'diffused in' the ancient evidence" ( 158 ). This of course means that any first-order, descriptive use of the term-where by "descriptive" Nongbri refers to the usage of the term as an "attempt to reproduce the classifications of the group of people being studied" (I 57 ) — must be abandoned.

Nongbri's project is ambitious and undoubtedly challenging. Nevertheless, he manages to offer a survey of the history of the term "religion" without neglecting the important issues that arise out of questions pertaining to how, why, and by whom religion is defined, used, and applied as a category. Before Religion is a concise and very well written introduction to the broader issue of the place of the term "religion" within academia, in which undergraduates will find various interesting topics and a good bibliography that can open new paths in their understanding and evaluation of their own categories and concepts. Additionally, scholars will find this volume interesting and a welcoming addition to a series of books — some way more hostile to the term "religion" than Nongbri's - that, more or less, have reshaped the way scholars of religion talk about their discipline and their classifications.

Nickolas P. Roubekas

University of Aberdeen 